\title{
Crisis and Image Repair at United Airlines: Fly the Unfriendly Skies
}

\author{
William L. Benoit \\ Department of Communication Studies, University of Alabama at Birmingham, \\ Birmingham, Alabama, USA
}

\begin{abstract}
In April 2017, United Airlines had a passenger removed from one of its airplanes. Video of the bleeding man being dragged off through the aisle went viral the next day. United's initial response attempted to downplay this offensive act (relying primarily on differentiation and mortification, but not really apologizing for this offensive act). This stance provoked outrage and ridicule. This study applies image repair theory (Benoit, 2015) to the discourse in this case study. United's CEO, Oscar Munoz, was forced to offer a "do-over," stressing mortification and corrective action that were actually directed to the offensive act. United finally arrived at the proper response, but it came too late to realize its full potential. This essay argues that corrective action can be an important strategy in crisis communication theory; it also explains that social media have changed the crisis situation (with nearly instant and widespread criticism) and compressed the time in which those accused of wrongdoing can respond.
\end{abstract}

KEYWORDS: Image repair; case study; United Airlines; social media; corrective action

On Sunday, April 9, 2017, United Airlines sought to substitute four flight crew members for passengers already seated on United flight 3411 traveling from Chicago, Illinois, to Louisville, Kentucky. Three passengers accepted travel vouchers, but United stopped short of offering the maximum amount possible, and no one else volunteered to leave the airplane. Chicago security personnel then physically removed a passenger, David Dao, from the flight. On Monday morning, Audra Bridges, a passenger on the flight, "posted a video of the incident on Facebook, which has been shared more than 49,00o times and viewed 3.8 million times" (Marotti \& Zumbach, 2017). The video of the incident showed a bloody, screaming man being dragged through the aisle and

CONTACT William L. Benoit, PhD•E-mail: wbenoit@uab.edu • Heritage Hall, University of Alabama at Birmingham, Birmingham, AL 35294

() 2018 by Journal of International Crisis and Risk Communication Research. All rights reserved. 
off the plane (Singh, 2017). Dao's injuries included a "concussion, a broken nose, and two lost teeth" (McCann, 2017).

United Airlines CEO Oscar Munoz initially tried to downplay the situation; rather than apologizing for his company's outrageous behavior toward Dao, he suggested that Dao's belligerent behavior caused the incident. Notably, Munoz apologized to the other passengers on the flight, but not to Dao. United's initial response was spread via social media, making things worse for United. A Harris Poll (2017) revealed that the percentage of consumers who thought United Airlines had a "bad" or "very bad" reputation soared from $7 \%$ in 2016 to $42 \%$ after the incident. A survey from Public Policy Polls found that " $40 \%$ of those surveyed believe United is the worst airline in the country" (GonzalesRamirez, 2017). Carol Gstalder, senior vice president at the Harris Poll, noted that "United's six-fold increase in negative corporate reputation sentiment shows us once again how quickly and severely a company's corporate reputation can be damaged" (Harris Poll, 2017). On Tuesday, shares of United stock dropped \$1.4 billion (Shen, 2017). Undeniably, United Airlines faced a serious crisis. This article analyzes United's attempt to repair its image in this debacle. First, I discuss corporate crisis communication in general and research applying image repair theory to corporate scandals. Then, I use image repair theory to analyze the company's statements in this case. Finally, I discuss implications of the analysis for theory and practice.

\section{Literature Review}

\section{Corporate Crisis Communication}

Scholars have brought a number of perspectives to bear on the topic of crisis communication. Three key works focused on crises in corporate communication: Hearit (2006) articulated the idea of crisis communication by apology, and Coombs (2012, 2013) developed situational crisis communication theory. The rhetoric of renewal, explicated by Seeger, Sellnow, and colleagues (e.g., Seeger \& Griffin-Padgett, 2010; Seeger, Ulmer, Novak, \& Sellnow, 2005; Sellnow \& Seeger, 2013; Ulmer, Seeger, \& Sellnow, 2007), is another important approach to crisis communication. Because a person's or organization's reputation is so important, 
crises usually prompt messages to control or eliminate damage. This analysis depends on image repair theory, so that literature will be examined more closely.

\section{Image Repair Theory}

Benoit (1995a, 1997, 2015) created image repair theory by drawing on rhetorical theory (Burke, 1970, 1973; Ware \& Linkugel, 1973; Scott \& Lyman, 1968). This approach to crisis communication discourse begins with two key assumptions: (a) Communication is a goal-oriented activity and (b) a fundamental goal of communication is maintaining a positive reputation. Image repair discourse is a response to actual or anticipated threats to face. Such threats consist of two elements: (a) an offensive act that is (b) attributed to the target (see Pomerantz's, 1978, analysis of complaints or Benoit, 2017; Benoit \& Glantz, 2017). Image repair theory identifies 5 general strategies and a total of 14 strategies (see Benoit, 2015; see Table 1).

The United crisis, a video of a passenger being dragged off an airplane followed by an inept initial response, cries out for corrective action. This strategy has been used frequently in image repair, with mixed results. This section reviews uses of corrective action that were relatively successful and other instances of this strategy that were less effective.

Following the first episode of Tylenol poisoning, Johnson and Johnson used denial, bolstering, and corrective action (tamper-resistant packaging). This image repair effort was remarkably effective. President Reagan initially attempted to deny knowledge of the Iran-Contra affair. He repeatedly stressed good intentions and tried to minimize perceived harms. Ultimately, however, evidence emerged that forced him to reverse his position, admitting responsibility and taking corrective action to prevent recurrence of similar problems. Only then did his popularity reverse its downward spiral.

AT\&T lost its long-distance telephone service in 1991 because of a power outage. At that time, air traffic control relied on land lines to direct airplane movement, so, in addition to the disruption of long distance, air travel was degraded. AT\&T published a full-page newspaper advertisement that effectively used mortification, corrective action, and 
TABLE 1 Typology of Image Repair Strategies

\begin{tabular}{|c|c|c|}
\hline Strategy & Definition & Example \\
\hline \multicolumn{3}{|l|}{ Denial } \\
\hline Simple denial & $\begin{array}{l}\text { did not perform act; act is } \\
\text { not harmful }\end{array}$ & $\begin{array}{l}\text { Tylenol did not poison } \\
\text { capsules }\end{array}$ \\
\hline Shift blame & $\begin{array}{l}\text { another committed the } \\
\text { offense }\end{array}$ & madman poisoned capsules \\
\hline \multicolumn{3}{|c|}{ Evade responsibility } \\
\hline Provocation & $\begin{array}{l}\text { offensive act just a response } \\
\text { to an earlier offense }\end{array}$ & $\begin{array}{l}\text { firm left state because of } \\
\text { new taxes }\end{array}$ \\
\hline Defeasibility & lack of information or ability & $\begin{array}{l}\text { executive not informed of } \\
\text { changed meeting time }\end{array}$ \\
\hline Accident & mishap & $\begin{array}{l}\text { tree fell on tracks, causing } \\
\text { train wreck }\end{array}$ \\
\hline Good intentions & meant well & $\begin{array}{l}\text { company believed changes } \\
\text { would help consumers }\end{array}$ \\
\hline \multicolumn{3}{|c|}{ Reduce offensiveness } \\
\hline Bolstering & $\begin{array}{l}\text { stress defender's good traits } \\
\text { or acts }\end{array}$ & $\begin{array}{l}\text { Exxon claimed "swift and } \\
\text { competent oil spill cleanup" }\end{array}$ \\
\hline Minimization & $\begin{array}{l}\text { offense less serious than it } \\
\text { appears }\end{array}$ & $\begin{array}{l}\text { few harmed by water } \\
\text { pollution }\end{array}$ \\
\hline Differentiation & $\begin{array}{l}\text { act less offensive than } \\
\text { other, similar acts }\end{array}$ & $\begin{array}{l}\text { Sears repairs were } \\
\text { preventative maintenance, } \\
\text { not fraud }\end{array}$ \\
\hline Transcendence & $\begin{array}{l}\text { act justified by more } \\
\text { important values }\end{array}$ & $\begin{array}{l}\text { research uses animals to } \\
\text { help create drugs for people }\end{array}$ \\
\hline Attack accuser & $\begin{array}{l}\text { reduce credibility of } \\
\text { accuser; suggest victim } \\
\text { deserved offense; shift } \\
\text { audience attention from act }\end{array}$ & $\begin{array}{l}\text { Pepsi owns restaurants } \\
\text { and competes for your } \\
\text { customers }\end{array}$ \\
\hline Corrective action & $\begin{array}{l}\text { fix problem or prevent } \\
\text { recurrence }\end{array}$ & $\begin{array}{l}\text { AT\&T promises to spend } \\
\text { billions to improve service }\end{array}$ \\
\hline Mortification & apologize & $\begin{array}{l}\text { AT\&T apologized for service } \\
\text { interruption }\end{array}$ \\
\hline
\end{tabular}

Note. See Benoit (1995a, 1997, 2015). 
bolstering to repair the company's image (Benoit \& Brinson, 1994). This strategy was employed successfully in this case.

In the early 1990s, Dow Corning was criticized for the alleged dangers of its breast implants. Its defense began with denial. Later, it used a mild form of mortification (i.e., saying it did not express its concerns for women adequately) without admitting to the dangers of its implants, and finally, Dow used corrective action when it ceased production of the implants (Brinson \& Benoit, 1996). The corrective action muted the criticism, although arguably, it should have come sooner.

In 1996, a secret tape recording of executives at Texaco was leaked to the public. African American employees were described in the conversation as "black jelly beans" who were "glued to the bottom of the jar" (Brinson \& Benoit, 1999, p. 484). These revelations prompted outrage, so the company developed several messages utilizing bolstering, corrective action, mortification, and shifting blame. The most interesting strategy in its successful defense was shifting the blame to "bad apples" in the company, who were punished.

British Petroleum (BP) put out a number of newspaper and television ads about the Gulf of Mexico oil spill (Benoit, 2015). The company used mortification, bolstering, and corrective action. Some of the spokespeople the company used were local residents. A novel element of BP's image repair effort was that it not only promised corrective action but also gave progress reports.

Other instances of corrective action were less successful. Exxon's response to the Valdez oil spill shifted the blame for the accident to Captain Hazelwood and for the delay in the cleanup to slow authorization from the state of Alaska and the U.S. Coast Guard. It attempted to minimize the size of the problem, bolstered its image as a concerned company, and promised corrective action to alleviate any damage. However, the state of Alaska and the U.S. Coast Guard were poor choices for targets for blame. Exxon's attempts to minimize the extent of the problem were graphically denied by television and newspaper coverage. Similarly, description of a slow and apparently inept cleanup undermined both its attempts to bolster its image and the credibility of its promised corrective action. Thus Exxon's image restoration campaign was relatively ineffectual. 
Union Carbide's response to the Bhopal, India, gas leak that killed thousands and injured hundreds of thousands comprised bolstering and corrective action in the form of aid to victims. Although these strategies were appropriate, they failed to address a very important question: What, if anything, would Union Carbide do to prevent another tragedy? Failure to answer this most important question undermined the image repair effort.

The California Department of Consumer Affairs accused Sears Auto Centers of consumer fraud in 1992. Sears employed newspaper advertisements, television spots, and other messages to carry its defense through two phases. At first, the company used denial and attack of accuser. When California's accusations were corroborated by accusations of auto repair fraud in New Jersey, Sears finally announced corrective action. It never apologized for fraud, and the defense was largely ineffectual (Benoit, 1995b), including corrective action that was not employed quickly enough to be effective.

U.S. Airways flight 427 crashed in September 1994 while approaching the Pittsburgh, Pennsylvania, airport, killing 132 people. The company took out full-page newspaper advertisements to repair its image. It made use of three image repair strategies: bolstering, denial, and corrective action. However, Benoit and Czerwinski (1997) characterized its proposed action as "pseudo-corrective action." The changes it proclaimed "were not designed to actually improve its safety, but simply to convince the flying public of USAir's current safety" (p. 51). This defense was ineffective.

Newt Gingrich was accused of improprieties in a multi-milliondollar book deal. One of the image repair strategies he employed was corrective action by returning the advance. Kennedy and Benoit (1997) argued that if the book deal were on the up and up-as Gingrich asserted-there would be no need to return the advance. Gingrich's action merely shifted when he would accrue the profits from the deal; it did not ensure that the deal was proper.

Garry Trudeau's comic strip Doonesbury advanced several criticisms of the tobacco industry, arguing that tobacco products are dangerous and addictive-and these accusations were intensified with the argument that tobacco products were deliberately marketed to children (Benoit \& Hirson, 2001). The Tobacco Institute (an industry 
organization) created a pamphlet to respond to the attack: Smoking and Young People: Where the Tobacco Industry Stands. The Tobacco Institute's message employed denial, corrective action, blame shifting, bolstering, and good intentions. However, these strategies did not work well together. Corrective action is not consistent with denial (there is no need to alter marketing procedures if the companies are not marketing to children); key accusations in the attack were ignored (the public widely believes tobacco to be dangerous); and the implementation of the strategies in discourse was weak (e.g., the pamphlet denied that advertising caused smoking without any evidence).

Several hundred people died in automobile crashes when Firestone tires failed ("blowouts"). The company attempted to shift blame to Ford (many of these accidents happened in Ford Explorer vehicles). Firestone used bolstering and denial, strategies that were undermined by its use of mortification and corrective action. Furthermore, the corrective action in this case was too vague to be persuasive (Blaney, Benoit, \& Brazeal, 2002).

Hurricane Katrina caused death, injury, dislocation, and property damage. President Bush was accused of leading a slow and inept response. He utilized bolstering, defeasibility, and corrective action to respond to these accusations. Bolstering could not counter his slow response, defeasibility portrayed Bush as not being in control of events, and his corrective action was too little, too late.

Grunenthal offered image repair for the birth defects that arose from its drug thalidomide. The company used mortification, corrective action (past and future), defeasibility, and differentiation. Its use of corrective action was vague, and the company waited almost 50 years before apologizing (Benoit, 2015). The New Orleans Saints football franchise was revealed to have paid bounties to players who hurt opposing players. The organization proffered a defense of mortification, corrective action: ineffectual, paying to hurt opposing players is terrible sportsman [person] ship (Benoit, 2015). Rupert Murdoch's News of the World was shown to have engaged in relentless phone hacking, with targets including victims of crimes. The mogul used mortification, corrective action, and compensation. However, his defense was not timely enough to be effective (Benoit, 2015).

These case studies indicate some of the conditions that influence 
the persuasiveness of corrective action. The defense should actually fix (and/or prevent future occurrences of) the problem. To have the best chance of success, the person or organization employing corrective action should do so in a timely fashion (note that in the contemporary environment of social media, corrective action should be used very quickly indeed). The defense should be internally consistent (e.g., do not deny the existence of a problem and propose corrective action).

\section{United Airlines's Defense}

United Airlines's image repair evolved through two phases. At first, the discourse attempted to downplay the offense, relying mainly on differentiation and mortification. United's initial response provoked outrage. The second phase appeared to emerge grudgingly, using mortification and corrective action. The "phases" of image repair have become highly compressed with the advent of social media (consider the time it took for the phases of President Reagan's Iran-Contra defense to develop).

\section{Differentiation: "Re-accommodating Passengers"}

United's CEO Oscar Munoz released a statement on the Monday afternoon following the event. He used bolstering, explaining that "all of us here at United" were upset by the event. He also offered two apologies (mortification): "I apologize for having to re-accommodate these customers" (Thomas, 2017; see also United News Release, 2017a) and for the "over-book situation" (McCann, 2017). Both of these apologies incorporated differentiation: "re-accommodate" sounds less offensive than "drag passengers off an airline," while "over-booked" sounds better than "we kicked a seated passenger off an airplane to make room for our employees." United had not gotten off to a good start in this crisis.

On Monday, Munoz also sent a letter to United employees, which quickly became public. In it, the CEO used provocation, characterizing Dao as "disruptive and belligerent." The CEO also put defeasibility into play, stating that "our agents were left with no choice but to call Chicago Aviation Security Officers to assist in removing the customer from the flight" (McCann, 2017). Munoz also employed bolstering, reassuring his employees, "I want to commend you for continuing to go above 
and beyond to ensure we fly right." Munoz declared that "treating our customers and each other with respect and dignity is at the core of who we are" (McCann, 2017). These utterances clearly implied that no wrongdoing occurred. Munoz did apologize to other passengers on the flight, but not to Dao (McCann, 2017). Observers were unlikely to see United's treatment of Dao as commendable or to believe that United's philosophy was "treating customers ... with respect."

\section{Mortification and Corrective Action: United's "Do-Over"}

On Tuesday, United's CEO apparently realized he was piloting his company into a hurricane; he radically changed the course of his defense. Munoz declared, "It's never too late to do the right thing" (Mutzabaugh, 2017; see also United Press Release, 2017c). He asserted that he was "disturbed" by the events of Sunday (McCann, 2017), enacting bolstering. He also offered another apology: "My deepest apologies for what happened." He explicitly included the victim (although he did not mention Dao by name): "I deeply apologize to the customer forcibly removed and to all of the customers aboard. No one should ever be mistreated this way." He also declared, "We take full responsibility" (McCann, 2017; see also United News Release, 2017b). Thus, in his "do-over," Munoz utilized mortification, saying that he was disturbed, that the offensive act was clearly wrong, and that he accepted responsibility for it (eventually).

Once United confessed that it had treated Dao badly, corrective action was needed. Munoz declared, "We will work to make it right" (McCann, 2017). He asserted, "I have committed to our customers and our employees that we are going to fix what's broken so this never happens again." He ended his statement by assuring his audience, "I promise you we will do better" (McCann, 2017). This phase of the image repair effort sounded sharply different from the prior phase. This is a clear illustration of corrective action.

On Wednesday, Munoz appeared on ABC's Good Morning America, saying that he felt "shame" when he watched the video, enacting mortification again. He reiterated his use of corrective action: "This can never-will never-happen again on a United Airlines Flight. That's my premise and that's my promise" (McCann, 2017). Later that day, the $\mathrm{CEO}$ announced that he would give a complete refund to everyone who 
had been on the flight (McCann, 2017), an instance of compensation.

The key elements of Phase 2 were repeated on Thursday. Mortification surfaced again when Munoz said, "We continue to express our sincerest apology to Dr. Dao." The CEO also returned to corrective action: We will "make this right"; "we cannot stress enough that we remain steadfast in our commitment to make this right" (McCann, 2017; United Press Release, 2017c). United's promise of corrective action was made more specific (Mann, 2017):

We are committing that United will not ask law enforcement officers to remove passengers from our flights unless it is a matter of safety and security. Second, we've started a thorough review of policies that govern crew movement, incentivising volunteers in this situation, how we handle oversold situations and an examination of how we partner with airport authorities and local law enforcement. Third, we will fully review and improve our training programs to ensure our employees are prepared and empowered to put our customers first.

These instances of corrective action aimed at preventing recurrence of the offensive act.

\section{Evaluation}

It was a mistake to drag a passenger off the airplane: The crisis probably could have been avoided if United had not waited until after passengers had boarded to squeeze its flight crew onto the airplane or, alternatively, if United had offered larger flight coupons to encourage passengers to deplane. Furthermore, if United had realized how damaging the video was, Munoz would never have tried to downplay its offense (characterizing its act as "re-accommodation" and as an instance of overbooking). However, United's initial response not only failed to put out the public relations fire but actually threw fuel on the flames, making the crisis even worse. Contrast Munoz's characterization of Dao as "disruptive and belligerent" with his assertion that "no one should ever be mistreated this way."

The initial defense used an interesting, and ineffectual, combination 
of differentiation and mortification (I do not argue that it is impossible for differentiation and mortification to work together; they did not work well in United's defense). United did not apologize for the actual offensive act depicted in the video but for two less offensive actions: "reaccommodating" a passenger and "overbooking." The millions who viewed the video would not be likely to agree that United was merely working to "re-accommodate" a passenger. For example, as @sassylibrarian1 wrote, "Nice to know 're-accommodate' on United now means 'drag you violently out of your seat"” (Thomas, 2017). Furthermore, the flight was not overbooked, despite Munoz's apology for the "over-book situation"; United wanted to put its employees onto a fully booked (and already boarded) flight. Munoz was correct to say that "it's never too late to do the right thing." That does not mean, however, that doing the "right thing" eventually will work as well as it would have worked if it had been implemented in a timely fashion. United eventually adopted a reasonable defense-apologizing for its actual offense and detailing multiple steps to prevent similar episodes-but this should have been its initial position.

\section{Discussion}

One implication of this case study is that the rapid rise of new technology is now a fundamental element of the crisis communication situation. Contemporary society has embraced social media and the capability of smartphones to record photos and/or video of instances of misbehavior. Furthermore, the ability of the Internet and social media to provide almost instantaneous distribution of incriminating pictures, videos, and other accusatory messages has forever altered crisis communication (see, e.g., Glantz \& Benoit, 2017). Persuasive attacks or criticisms are an important component of the current media environment. Corporations such as United Airlines are often very conservative. However, that stance is at odds with the need to react almost instantaneously to crises.

United Airlines had previously suffered Internet-facilitated damage to its image. United baggage handlers damaged a guitar in transit; when the victim received the run-around from United, a video called United 
Breaks Guitars went viral (Carroll, 2009) and forced the company to address the offensive act. However, it does not appear as if the company learned its lesson. The Internet allowed the latest crisis to unfold seemingly at hyperspeed, with the offensive act committed on Sunday, the initial defense and outraged reactions occurring on Monday, and the revised defense appearing on Tuesday. It is vital for corporations, organizations, and individuals to understand the nature of our current media environment.

Corporate image repair efforts, as in political image repair (Benoit, 1982, on Watergate; Benoit, Gullifor, \& Panici, 1991, on Reagan), have evolved through phases before (see, e.g., Benoit, 1995b, on Sears; Brinson \& Benoit, 1996, on Dow Corning). The simple fact that Munoz felt forced to enact a do-over is clear evidence that his initial stance was ineffectual. The new position was the right one; unfortunately for United, it came too late-and shifting his position so violently undermined Munoz's credibility. Another implication of this case study is the idea that it is not enough to apologize for something-one must apologize for the perceived offense. Using mortification is likely to damage face: No one enjoys confessing wrongdoing. Munoz's attempt to limit the embarrassment of mortification by reducing the offensiveness of the offensive act for which he apologized-apologizing for "re-accommodating" a passenger rather than apologizing for dragging a bloody passenger off the plane-backfired as the response to the video mounted. It is a wonder that United's stockholders have not reaccommodated Munoz by freeing him for other employment opportunities.

\section{Conclusion}

This essay reinforces the importance of corrective action as a potential strategy in crisis communication theory. Initially, situational crisis communication theory included corrective action as an option for crisis communication (see Coombs, 1998; Coombs \& Holladay, 2004). However, later incarnations of the theory omitted this important possibility (Coombs, 2012; see also Coombs \& Holladay, 1996). Corrective action is not always appropriate, nor is it necessarily persuasive. However, it must be a strategy in the toolbox of crisis communication. 
William L. Benoit, $\mathrm{PhD}$, is professor of communication studies at the University of Alabama, Birmingham. He developed the theory of image repair to help understand what people, groups, and organizations can say when accused or suspected of wrongdoing.

\section{References}

Benoit, W. L. (1982). Richard M. Nixon's rhetorical strategies in his public statements on Watergate. Southern Speech Communication Journal, 47, 192-211. https://doi.org/10.1080/10417948209372526

Benoit, W. L. (1995a). Accounts, excuses, apologies: A theory of image restoration strategies. Albany, NY: State University of New York Press.

Benoit, W. L. (1995b). Sears' repair of its auto service image: Image restoration discourse in the corporate sector. Communication Studies, 46, 89-105. https://doi.org/10.1080/10510979509368441

Benoit, W. L. (1997). Image restoration discourse and crisis communication. Public Relations Review, 23, 177-186. https://doi.org/10.1016/s0363 -8111(97)90023-0

Benoit, W. L. (2015). Accounts, excuses, apologies: Image repair theory and research (2nd ed.). Albany, NY: State University of New York Press.

Benoit, W. L. (2017). Criticism of actions and character: Strategies for persuasive attack extended. Relevant Rhetoric, 8. Retrieved from http://relevantrhetoric .com/CriticismofActionsandCharacter.pdf

Benoit, W. L., \& Brinson, S. (1994). AT\&T: Apologies are not enough. Communication Quarterly, 42, 75-88. https://doi.org/10.1080/0146337940936 9915.

Benoit, W. L., \& Czerwinski, A. (1997). A critical analysis of USAir's image repair discourse. Business Communication Quarterly, 60, 38-57. https:// doi.org/10.1177/108056999706000304

Benoit, W. L., \& Glantz, M. (2017). Persuasive attack on Donald Trump in the 2016 Republican primaries. Lanham, MD: Lexington Books.

Benoit, W. L., Gullifor, P., \& Panici, D. A. (1991). President Reagan's defensive discourse on the Iran-Contra affair. Communication Studies, 42, 272-294. https://doi.org/10.1080/10510979109368342.

Benoit, W. L., \& Henson, J. R. (2009). President Bush's image repair discourse 
on Hurricane Katrina. Public Relations Review, 35, 40-46. https://doi .org/10.1016/j.pubrev.2008.09.022

Benoit, W. L., \& Hirson, D. (2001). Doonesbury versus the Tobacco Institute: The Smoke Starters' Coupon. Communication Quarterly, 49, 279-294. https://doi.org/10.1080/01463370109385629.

Benoit, W. L., \& Lindsey, J. J. (1987). Argument strategies: Antidote to Tylenol's poisoned image. Journal of the American Forensic Association, 23, 136-146.

Blaney, J. R., Benoit, W. L., \& Brazeal, L. M. (2002). Blowout! Firestone’s image restoration campaign. Public Relations Research, 28, 379-392. https://doi .org/10.1016/s0363-8111(02)00163-7

Brinson, S., \& Benoit, W. L. (1996). Dow Corning's image repair strategies in the breast implant crisis. Communication Quarterly, 44, 29-41. https://doi .org/10.1080/01463379609369998

Brinson, S. L., \& Benoit, W. L. (1999). The tarnished star: Restoring Texaco's damaged public image. Management Communication Quarterly, 12, 483-510. https://doi.org/10.1177/0893318999124001

Burke, K. (1970). The rhetoric of religion. Berkeley, CA: University of California Press.

Burke, K. (1973). The philosophy of literary form (3rd ed.). Berkeley, CA: University of California Press.

Carroll, D. (2009). United breaks guitars. Retrieved from https://www.youtube .com/watch?v=5YGc4zOqozo

Compton, J. (2014). Arby's image repair tactics as a public relations strategy. Public Relations Review, 40, 122-124. http://dx.doi.org/10.1016/j.pubrev .2013 .11 .022

Coombs, W. T. (1998). An analytic framework for crisis situations: Better responses from a better understanding of the situation. Journal of Public Relations Research, 10, 177-191. https://doi.org/10.1207/s1532754xjprr1003_02 Coombs, W. T. (2012). Ongoing crisis communication: Planning, managing, and responding ( $3 \mathrm{rd} \mathrm{ed}$.$) . Los Angeles, CA: Sage.$

Coombs, W. T. (2013). Situational theory of crisis: Situational crisis communication theory and corporate reputation. In C. E. Carroll (Ed.), Handbook of communication and corporate reputation (pp. 262-278). Malden, MA: John Wiley.

Coombs, W. T., \& Holladay, S. J. (1996). Communication and attributions in a crisis: An experimental study in crisis communication. Journal of Public Re- 
lations Research, 8, 279-295. https://doi.org/10.1207/s1532754xjprro804_04

Coombs, W. T., \& Holladay, S. J. (2004). Reasoned action in crisis communication: An attribution theory-based approach to crisis management. In D. P. Millar \& R. L. Heath (Eds.), Responding to crisis: A rhetorical approach to crisis management (pp. 95-115). Mahwah, NJ: Lawrence Erlbaum.

Glantz, M., \& Benoit, W. L. (2017). The world's all Atwitter: Image repair discourse on social media. In L. L. Austin \& J. Jin (Eds.), Social media and crisis communication (pp. 168-179). New York, NY: Routledge.

Gonzales-Ramirez, A. (2017, April 21). United Airlines is more popular than President Trump. Refinery29. Retrieved from http://www.refinery29 .com/2017/04/150994/united-airlines-president-trump-approval-ratings -poll

Harris Poll. (2017, May 1). United Airlines' corporate reputation takes a nose dive: Negative perceptions of company's reputation jump 500 percent in April. Retrieved from http://www.theharrispoll.com/business/United-Airlines -Reputation-Nose-Dive.html

Hearit, K. M. (2006). Crisis management by apology: Corporate response to allegations of wrong-doing. Mahwah, NJ: Lawrence Erlbaum.

Kennedy, K. A., \& Benoit, W. L. (1997). The Newt Gingrich book deal controversy: A case study in self-defense rhetoric. Southern Communication Journal, 63, 197-216. https://doi.org/10.1080/10417949709373055

Marotti, A., \& Zumbach, L. (2017, April 10). Passenger dragged from United flight; CEO calls it "upsetting event." Chicago Tribune. Retrieved from http://www.chicagotribune.com/business/ct-united-drags-passenger-0411 -biz-20170410-story.html

McCann, E. (2017, April 14). United's apologies: A timeline. New York Times. Retrieved from https://www.nytimes.com/2017/04/14/business/united -airlines-passenger-doctor.html?_r=1

Mutzabaugh, B. (2017, April 11). United CEO issues a second apology, "I promise you we will do better." USA Today. Retrieved from https://www.usatoday .com/story/travel/flights/todayinthesky/2017/04/11/full-text-united-ceo -munoz-apologizes-flight-3411-pledges-review/100336992/

Pomerantz, A. (1978). Attributions of responsibility: Blamings. Sociology, 12, 115-121. https://doi.org/10.1177/003803857801200107

Seeger, M. W., \& Griffin-Padgett, D. R. (2010). From image restoration to renewal: Approaches to understanding postcrisis communication. Review 
of Communication, 10, 127-141. https://doi.org/10.1080/15358590903545263 Seeger, M. W., Ulmer, R. R., Novak, J. M., \& Sellnow, T. (2005). Post-crisis discourse and organizational change, failure, and renewal. Journal of Organizational Change Management, 18, 78-95. https://doi.org /10.1108/09534810510579869

Sellnow, T. L., \& Seeger, M. W. (2013). Theorizing crisis communication. Malden, MA: Wiley-Blackwell.

Singh, Gurpreet. (2017). United Airlines dragging passenger from plane. Retrieved from https://www.youtube.com/watch? $\mathrm{v}=4 \mathrm{fSDFqv} 4 \mathrm{Dkw}$

Smith, E. (2012). Corporate image and public health: An analysis of the Philip Morris, Kraft, and Nestle websites. Journal of Health Communication, 17, 582-60o. https://doi.org/10.1080/10810730.2011.635776

Thomas, L. (2017, April 10). United CEO says airline had to "re-accommodate" passenger, and people are having a riot. CNBC. Retrieved from http://www .cnbc.com/2017/04/10/united-ceo-says-airline-had-to-re-accommodatepassenger-and-twitter-is-having-a-riot.html

United News Releases. (2017a, April 10). Response to United Express flight 3411 [News release]. Retrieved from http://newsroom.united.com/news -releases?item $=124753$

United News Releases. (2017b, April 11). Statement from United Airlines CEO Oscar Munoz on United Express flight 3411 [News release]. Retrieved from http://newsroom.united.com/news-releases?item $=124755$

United News Releases. (2017c, April 13). Statement on press conference [News release]. Retrieved from http://newsroom.united.com/news-releases?item $=124756$ 